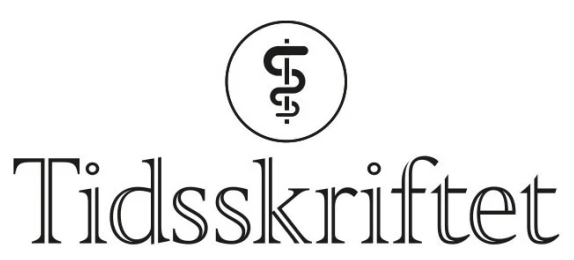

DEN NORSKE LEGEFORENING

\title{
Arne Johan Refsdal
}

\author{
MINNEORD
}

KAREN SOFIE KOSS

SIGURD KULSENG-HANSSEN

MARIT KRISTOFFERSEN

UNNI KIRSTE

ØYSTEIN MAGNUS

PER E. BØRDAHL

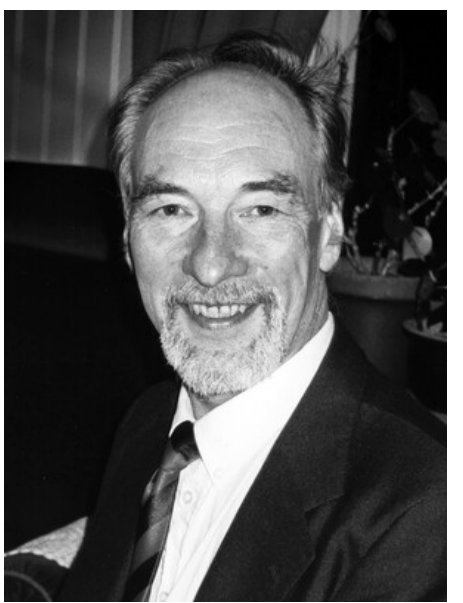

Vår gode venn og kollega, tidligere avdelingsoverlege Arne Johan Refsdal, døde 20. juli 2021, 84 år gammel.

Arne vokste opp i Vang på Hedmarken og studerte medisin i Kiel, der han traff Karin, hans livsledsager gjennom 63 år. Han ble cand.med. i 1962. Etter turnus i Kongsvinger og Valdres og et år på St. Josephs hospital i Fredrikstad fortsatte han sin spesialistutdanning ved Centrallasarettet i Eskilstuna og Aker sykehus. På Aker var han også reservelege, og i 1974 fikk han samme stilling ved gynekologisk avdeling på Radiumhospitalet. 
I 1982 ble Arne assisterende overlege i gynekologi og fødselshjelp ved Bærum sykehus, og året etter ble han avdelingsoverlege. Avdelingen ble i hans tid radikalt endret. I starten var det vel 6oo fødsler om året, syv år senere tre ganger så mange. De første årene var det firefem spesialister som, sammen med meget kompetente sykepleiere og jordmødre, tok seg av det store antallet fødsler samt gynekologien i et stort område. Antallet leger økte, etter hvert også med spesialistkandidater.

Arne var en dyktig miljøbygger, og han ansatte en stab med bred utdannelse og forskjellig spisskompetanse. Selv var han en eminent kirurg og lærer. Han var en utpreget kliniker og en glimrende leder som la vekt på at medarbeiderne fikk utvikle seg faglig. Han fremstod som den første blant likemenn, og vi var aldri i tvil om hvem som skulle trekke konklusjonen etter faglige diskusjoner. Det var han heller ikke selv. Han var dypt respektert av staben og svært godt likt av pasientene.

Han var friluftsmann på sin hals, hundeelsker og fuglejeger. Sammen med Karin oppdro han settere og vorstehhunder med kjærlighet og stor dyktighet. Rypejakten var årets høydepunkt. Vi er flere som har gode minner fra jaktturene i Hemsedalsfjellene.

Under en skitur med hundene på Sollihøgda i 1992 fikk Arne et hjerneslag, noe som medførte at han sluttet som avdelingsoverlege. Med sterk vilje og pågangsmot kjempet han seg tilbake, men flere fysiske plager rammet ham. Etter år med hjerteproblemer ble han transplantert for 20 år siden. Han gjorde det beste ut av situasjonen og bevarte livsgleden.

Arne var familiekjær, og våre tanker går til Karin, barn, barnebarn og oldebarn. For oss som arbeidet sammen med ham, var han en kollega og læremester vi aldri glemmer.

Vi lyser fred over Arne Johan Refsdals minne.

Publisert: 25. oktober 2021. Tidsskr Nor Legeforen. DOI: 10.4045/tidsskr.21.0640

(C) Tidsskrift for Den norske legeforening 2023. Lastet ned fra tidsskriftet.no 26. april 2023. 